\title{
A Study of the Differences Between China and UK Classroom Teaching in Middle Schools Based on a BBC Documentary
}

\author{
MIAO Yi-yi \\ Ningbo Dahongying University, Ningbo, China
}

\begin{abstract}
This paper aims to analyze the differences between China and UK classroom teaching in middle school based on a case study of a BBC documentary, Are Our Kids Tough Enough-Chinese School. The author found that there were many significant differences between the two countries in terms of the relationship between teacher and student, classroom teaching style and teaching methods.
\end{abstract}

Keywords: classroom teaching, teacher-student relationship, class management mode

\section{Introduction}

Nowadays, all the countries around the world pay more attention to education. The UK and China are both countries with a long traditional educational history. Both of them hope to absorb the merits from the other to improve the quality of their education.

However, due to the different development in politics, economics, and culture in two countries, there exist big distinctions in terms of education idea or education method. So this research focuses on the study of the differences in education, based on the case study of a BBC documentary Are Our Kids Tough Enough-Chinese School.

\section{Status Quo}

In terms of the relationship between students and teachers in China, teachers are highly respected by others and students are used to obeying the teachers.

In terms of the teaching methods, Francis McGonigal (2002) from Birmingham commented that "Chinese methods encouraged learning by rote, rather than independent thinking”. Chinese teachers like to give the answer directly. Because of this, a lot of students lost the ability of independent thinking.

However, teachers tend to be friends with their students in Britain. As Durkin ( 2004 ) said "A pattern of social constructivist learning environment, where a teacher acts as a guide and facilitator considering the students as their equals rather than being a guru-like role of absolute authority and knowledge". Hofstede (2012) also said that "the entire system is based on student's well-developed need for independence and the quality to an extent is determined by the excellence of students". So in Britain teachers think a good student should not only have good grades but also have independent thinking ability and know the ways how to face the challenges. Besides,

MIAO Yi-yi, undergraduate, School of Humanities, Ningbo Dahongying University. 
individual personalities are respected.

\section{Research Design}

\section{Research Method}

Based on the related, literature, review from the papers, journals, or websites, the main research method is a case study method that studies a BBC Documentary: Are Our Kids Tough Enough-Chinese School.

The documentary is talking about a bold and unique experiment, Hampshire school which is one of the top comprehensive school in Britain has invited five teachers from leading schools in China to teach 50 of pupils in Grade 9, aged 13 and 14, for four weeks.

\section{Research Questions}

What is different relationship between teachers and students? Should we give the children a happy childhood or urge them study hard for their future? Should we cultivate students' spirit of collectivism or encourage them to keep their personality?

\section{Results and Discussion}

\section{Different Relationship and Teaching Approach Between Teachers and Students}

In China, the relationship between teachers and students is just like that between parents and children. The teachers are highly respected by students and students are used to obeying the teachers. It is true that teachers often put on a face strictly in class to let students know they are now in a very competitive world and they should try their best in their studies. However, after class, teachers are really kind. They often find time to talk with children and try to know what they are thinking about.

However, in Britain, teachers tend to be friends with their students. The relationship between them is more equal. The class is much smaller. So the teaching approach is more personal and friendly. Besides, teachers encourage students to raise questions. They also believe there is not only one right answer. In the meanwhile, they hope to work, study, and make progress with their classmates together.

\section{Difference Between Educational Ideas}

In China, teachers prefer to teach knowledge to students. They stress more on the results rather than on the learning process. Because of this, they prefer to give the standard answer directly even in science class which needs a large number of experiments. That does no good to cultivating students' ability of independent thinking. Therefore, the students are always ready to accept the correct answer from the teacher blindly.

Compared with Chinese teachers, British teachers pay more attention to the development of student's ability. They think children should know how to study independently. Teachers and parents know that they cannot do everything for children, so they should only play a facilitator role. In class, teachers always put forward many questions to let students think about and ask students to solve problems by themselves. During the scientific experiments, they do not tell every experimental step. Instead, they encourage students to find the answers by themselves and summarize experience in failures. In their eyes, a good student should not only have good grades but also have independent thinking ability and know how to face the challenges. Furthermore, they also need to cultivate their individual personality. 


\section{Different Class Management Modes}

Class discipline. In China, teachers hope students can be absolutely quiet and focused attention on what the teachers say in the class. Students are expected to be quiet and obedient. Accordingly, students take a lot of notes in class quietly.

However, British teachers give relatively more freedom to students. They think students should have a comfortable study environment. The students in UK are encouraged to express their own thoughts in class. Even when pupils sit in the class with legs on chairs, chewing gums, and so on, it is not considered as an offence by the British faculty but rather a kind of good communication with the teacher. But for Chinese teachers, these behaviors are definitely not allowed in class. Moreover, what shock the Chinese teacher is that one girl cried heavily and got out of class just because her favorite pop singer quit the band.

Learning time. Students in China often spend nearly nine hours for studying at school and spend nearly five or several more hours on homework after class in a day. All in all, the kids in the Chinese school have almost as twice long as their counterparts under UK classroom teaching in class. Chinese teachers ask students to attend to the class before seven o'clock in the morning and stay at school for 12 hours one day. Besides, there are only two short rest times for students to have lunch and have breaks. Teachers believe long days and strict discipline can contribute to superior learning results.

However, in UK, students spend less time on study both in school and at home. They could have more free time to read extra-curricular books to gain more knowledge and do some interesting out-of-class activities, to enjoy childhood rather than working hard for the test.

\section{Reflection on the Results of the Academic Test}

As shown in Table 1, it obviously seems that the Chinese teaching approach achieve much better results.

Table 1

The Results of the Academic Test

\begin{tabular}{lll}
\hline & $\begin{array}{l}\text { The average marks of students under classroom } \\
\text { teaching of Chinese teachers }\end{array}$ & $\begin{array}{l}\text { The average marks of students under UK classroom } \\
\text { teaching }\end{array}$ \\
\hline Math & 67.74 & 54.84 \\
Mandarin & 46.88 & 36.46 \\
Science & 58.33 & 50 \\
\hline
\end{tabular}

It seems that the students under Chinese teachers classroom teaching approach had better academic results during this experiment. Obviously, the students who get high scores or get progress are very happy. However, most of them also think that "Chinese education is not the most encouraging thing". Just as one child said "I think the Chinese education system seems like sort of an industrial process. You get batches of really intelligent kids who have the same work ethic". Admittedly while most of them improve their grades and attained a high state of inner happiness from the grade for the time being, it is true that in their eyes they also felt so tired of their learning.

Admittedly, it is not ideally rigorous if we compare the differences between China and UK classroom teaching in middle school only based on a BBC documentary. However, it can be obviously seen from the documentary that British education pays more attention to training students' ability, rather than focuses on students' grades. 


\section{Conclusion}

This study compares the differences between China and UK classroom teaching in middle school. British students' are accustomed to considering things independently, and they have their own unique way to solve the problem or to keep the relationship with others. However, their theoretical knowledge is relatively weaker. Chinese students spend too much time on learning the subjects in school and though they have a better academic grades, but their ability such like independent thinking, the capacity for innovation and other abilities are not good enough.

Actually, whether in China or in Britain, when students get good grades, they all feel happy and are proud of themselves. To a certain extent, the outstanding grades can show the students study attentively during the learning process. However, if students spend too much time on study and lack of rest, they will feel tired or even tired of studying. Thus, the education authorities in these two countries should regulate students' learning time appropriately and enrich after-school activities to let students have a happy childhood.

\section{References}

Bishop, J., \& Verleger, M. (2013). The flipped classroom: A survey of the research. Paper presented at The 120th ASEE Annual Conference \& Exposition, Atlanta, GA.

Bransford, D, L. B., \& Cocking, R. (1999). How people learn: Brain, mind, experience and school. Washington, DC: National Academy Press.

David, C. P. (1995). Ideology and educational reform. Colorado: Westview Press, Inc..

FAN, M. (2012). 中小学课堂教学中“非期待答案”研究 (The research for “Not Looking Forward to the Answer” under the primary and secondary schools classroom teaching). 西安：陕西师范大学.

HE, Y. P. (2008). 中英课堂教学评价表之比较 (The comparison between China and English classroom teaching evaluation). 中 小学管理, 4, 50-52.

Kirst, R. (1983). The sociology of school organization. New York: Methuen Co., Ltd..

LIU, C. B. (2009). 中西方课堂文化对比研究 (The comparative research between China and Western classroom culture). 生丹江教育学院举报, 4, 82-83.

Phye, D. (1997). Handbook of classroom assessment. San Diego, CA: Academic Press.

QI, J. (2012). 体悟教学研究 (Connect the teaching research). 南京：南京师范大学.

Robert, E. (1987). Slavin research on cooperative learning. ML: Taylor \& Francis.

Tyack, D., \& Cuban, L. (1995). Tinkering toward utopia: A century of public school reform. Cambridge, Mass.: Harvard University Press.

WANG, Y. M. (2011). 论教学习惯 (The theory of teaching habits). 南京: 南京师范大学.

WANG, Y. M., \& WU, J. R. (2013). 中英高等学校课堂教学比较探索 (The comparison and exploration between China and English classroom teaching). 科学咨询(科技管理), 48, 133-135.

Wragg, E. C. (1999). Introduction to classroom observation (2nd). London \& New York: Routledge.

XU, D. L. (2011). 中西方课堂教学的比较研究 (The comparative research between China and Western classroom teaching). 科技向导, 29, 11 .

YAN, Y. (2011). 中英课堂教育异同之我浅见 (The difference between China and English classroom teaching). 金属世界, 4, 69-70.

ZHANG, L. Z. (2011). 课堂教学视域下的教师实践性知识研究 (The teachers' practical knowledge research under classroom teaching). 吉林: 东北师范大学.

ZHANG, Y. X. (2013). 中英高校课堂教学比较研究 (The comparative research between China and English classroom teaching in high school). 中国电力教育, 1, 37-47.

ZHOU, B. (2010). 中英课堂教学模式的跨文化比较 (The cross-cultural comparison between China and English classroom teaching model). 上海教育科研, 10, 46-47. 